\title{
Proposal and Evaluation of the Competency Model of the Teacher at the University Department
}

\author{
Blanka Bazsová \\ VŠB-Technical University of Ostrava, Ostrava, Czech Republic
}

\begin{abstract}
Performance supported by competencies is very important for every organization. Employees play the key role in the achieving of the performance. Organizations are aware of the importance of improving competencies of its employees. They develop them by organizing training courses. Modern trends in human resources management progressively press for more and more complex assessment of employees based on the networking performance model with the competency model. Nor is it otherwise in the field of higher education. Universities evolve pressure to increase especially the scientific performance. Therefore it is necessary to develop the teacher's competences. The goal of this article is to create a competency model of the teacher at the department by using multi-criteria decision making method - analytic hierarchy process (AHP) — to determine the weight of individual competencies represented in this model. The competency model can play an important role in evaluating the work of employees and significantly contribute to the objectification of rewarding system and human resources management at the department.
\end{abstract}

Keywords: AHP, competency, evaluation, teacher

\section{Introduction}

Competency expresses the ability to perform a specific job. Competence expresses suitability for a particular performance. This is an assumption that an employee is qualified for a particular performance (Hronik, 2007). Many authors tend to define competence as a set of knowledge, skills, abilities, and motivation for a given position. Competency model is important for creating the preconditions for the company competitiveness. Koubek (2007) pointed out that competency model of each work position is important for the assessment of employees and their comparison. It is based on permanent monitoring of capabilities, experience, and skills of employees. This can be the starting point for creating a system of education in the organization. It is a part of the comprehensive evaluation of the employee performance. It is also a part of the performance management (Wagnerova, 2008). Rehacek (2015) argues that competency models are a means to implement the strategy and its continuous verification. In order to enable the employees to realize the performance, they must have such prerequisites (Rehacek, 2015). The assessment by using competency model is a new approach to the

Acknowledgements: This work was supported within Operational Programme Education for Competitiveness-Project No. CZ.1.07/2.3.00/20.0296.

Blanka Bazsovạ́, Ing. Ph.D., Department of Systems Engineering, Faculty of Economics, VŠB-Technical University of Ostrava, Ostrava, Czech Republic.

Correspondence concerning this article should be addressed to Blanka Bazsová, VŠB-Technical University of Ostrava, 17. listopadu 15/2172, Poruba, Ostrava 70833, Czech Republic. 
organization effectiveness (Armstrong, 2009). Competency models and assessment based on competency models are used in all spheres of business activity. They cannot avoid also the area of education. For universities and schools, it is very important to have a professional team of experts who, in the process of learning and exchange of information, ideas, and data, apply not only their knowledge, but can also apply their acquired skills, experience and use both traditional and non-traditional and modern approaches that facilitate perception and understanding of the taught material. The methodology for creating competency models is becoming increasingly important especially now, when (as emphasized by Majovska, 2014) cognitive approaches and use of information technology come into the spotlight. Countries which perceive the importance of knowledge and sharing as their important potential for further development are called knowledge-based society. The development of cognitive technologies influences all society transformations from the industrial or the information society to the knowledge based society. There is no uniform classification of competencies in the literature. Breakdown of competencies should always suit the conditions of the organization in which competencies are grouped into competency models. Competency models can have as simple, the so called single-stage structure, so as complex, i.e. multistage structure. It always depends on the needs and requirements of the organization.

\section{Methodology}

Analytical Hierarchy Process (AHP) is a method of multi-criteria evaluation. It is based on a definition of each group of criteria and sub-criteria and an assessment of their importance-global significance for the criteria and local significance for the sub-criteria. The hierarchical structure represents the system and its elements, which are grouped and each element influences other elements (Ramik \& Perzina, 2008).

$$
S=\left(\begin{array}{cccc}
1 & S_{12} & S_{13} \ldots & S_{1 n} \\
1 / S_{12} & 1 & S_{23} \ldots & S_{2 n} \\
1 / S_{13} & 1 / S_{23} & 1 \ldots & S_{3 n} \\
1 / S_{1 n} & 1 / S_{2 n} & 1 / S_{3 n} \ldots & 1
\end{array}\right)
$$

where $S=\left\{\mathrm{s}_{\mathrm{ij}}\right\}$, where $i, j=1,2, \ldots, \mathrm{n}$.

$$
s_{i j} \approx \frac{w_{i}}{w_{j}}
$$

This method is often used in the field of strategic management. The importance is determined by mutually comparing the criteria within one group and between the groups. Local significance represents the importance of each sub-criterion in relation to the parent criterion. The sum of local significances is equal to one (100\%). The sum of global significances must also be equal to one (100\%). When calculating significances, Saaty's (1980) matrix of mutual comparison of all criteria to each other is used. The resulting significance is equal to the geometric mean of the product of the individual paired comparisons. Saaty (1980) uses the 9-escalate scale of the criteria evaluation (see Table 1).

The Saaty's matrix has two main attributes-reciprocity and consistency. The condition of reciprocity is considered as

$$
s_{i j}=\frac{1}{s_{j i}}
$$


Table 1

Saaty's Criteria Evaluation

\begin{tabular}{ll}
\hline Value & Criteria evaluation \\
\hline 1 & Equal importance among elements $i$ and $j$ \\
3 & Moderate importance of $i$ element before $j$ element \\
5 & Strong importance of $i$ element before $j$ element \\
7 & Very strong importance of $i$ element before jelement \\
9 & The extreme importance element $i$ before $j$ \\
\hline
\end{tabular}

Consistency is evaluated by ratio of consistency (CR). The value of the consistency must be $\mathrm{CR} \leq 0.1$, where

$$
C R=\frac{C I}{R I}
$$

where $\mathrm{RI}$ is the random index,

when

$$
C I=\frac{\lambda_{\max }-n}{n-1} \approx \frac{w_{i}}{w_{j}}
$$

where $\lambda_{\max }$ is the own number and $n$ is number of criteria.

We determine the weight of each criterion according to the geometric mean

$$
w_{i}=\frac{\left(\prod_{j=1}^{n} s_{i j}\right)^{1 / n}}{\sum_{j=1}^{n}\left(s_{i j}\right)^{1 / n}}
$$

The final rating is then expressed in the following relationship

$$
U_{i}=\sum_{j=1}^{k} u_{i j} \times w_{j}
$$

where $U_{i}$ represents the overall significance of the variant I with respect to the objective of the decision-making process, $u_{i j}$ expressed the significances of the variants for the individual criteria, and $w_{j}$ expresses the significance $j$ of that criterion (Bazsova, 2015).

\section{Research Design}

The research aim is to create a competency model of a teacher at the university. The competences should be derived from the requirements on the performance. The performance is divided into two groups at the universities in the Czech republic-pedagogical and scientific performance (see Figure 1). The groups of performance can be measured by indicators - scientific and pedagogical (see Figure 2).

Using a method based on expert evaluation, groups of competencies that will serve as evaluation criteria are determined. Also, their importance (preference) using multi-criteria decision, namely the AHP method will be determined. This method is based on the paired evaluation of the individual criteria. It is therefore the appropriate tool for objectification of decisions in different areas of life. The created competency model will be evaluated for four academic employees of the department, who create a set of possible solutions. To be able to create a competency model of the academic employee, we have, as well as in other areas of business, to base on 
a philosophy based on the processes and strategies of the organization as such. The main processes in the university are education spheres and research activities. Educational or teaching activities relate to the purpose for which the university was established, namely providing education to all sections of the population at various levels and degrees - bachelor's, master's, and doctoral. The aim of the research activities is to support the educational process and application of the latest scientific knowledge. Results of the research activities serve as a support tool for the learning process. In connection with this, we can hypothesize that the created competency model of the academic employee should take into account the needs of students. Success of students and the effectiveness of the perception of knowledge in the fields offered by the university and presented by the academic employees depend on their level of competence. If we go out and apply the draft competencies by Hronik (2007), general and specific competences would be the centre of our attention. With regard to the implementation of the above main processes, this idea has expanded and groups of competencies-language, general, computer, managerial, and those of professional growth - have defined. These groups have further divided into sub-competencies shown in Figure 3.

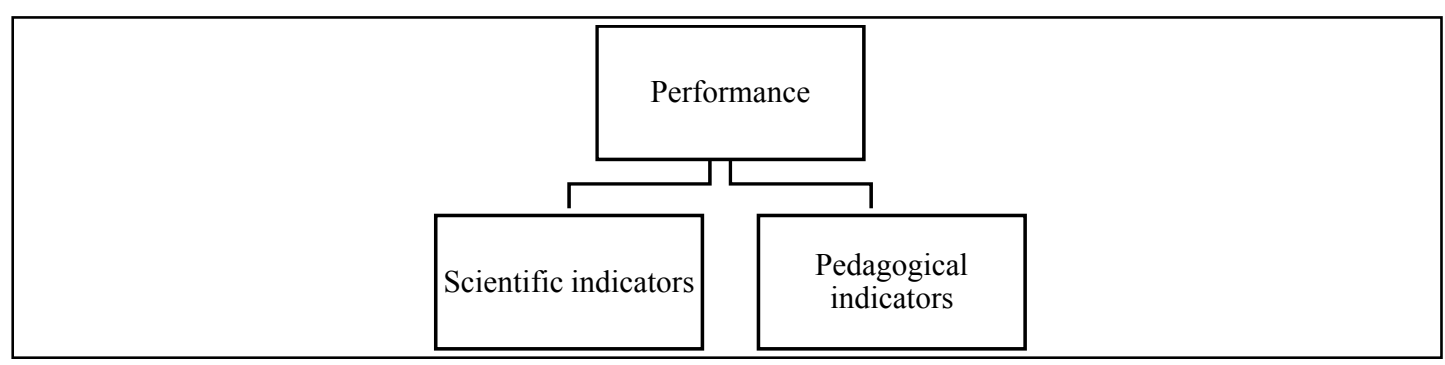

Figure 1. Main groups of performance indicators at the university according to the main processes.



Figure 2. Detail of the current indicators inside the performance evaluating process at the universities. 


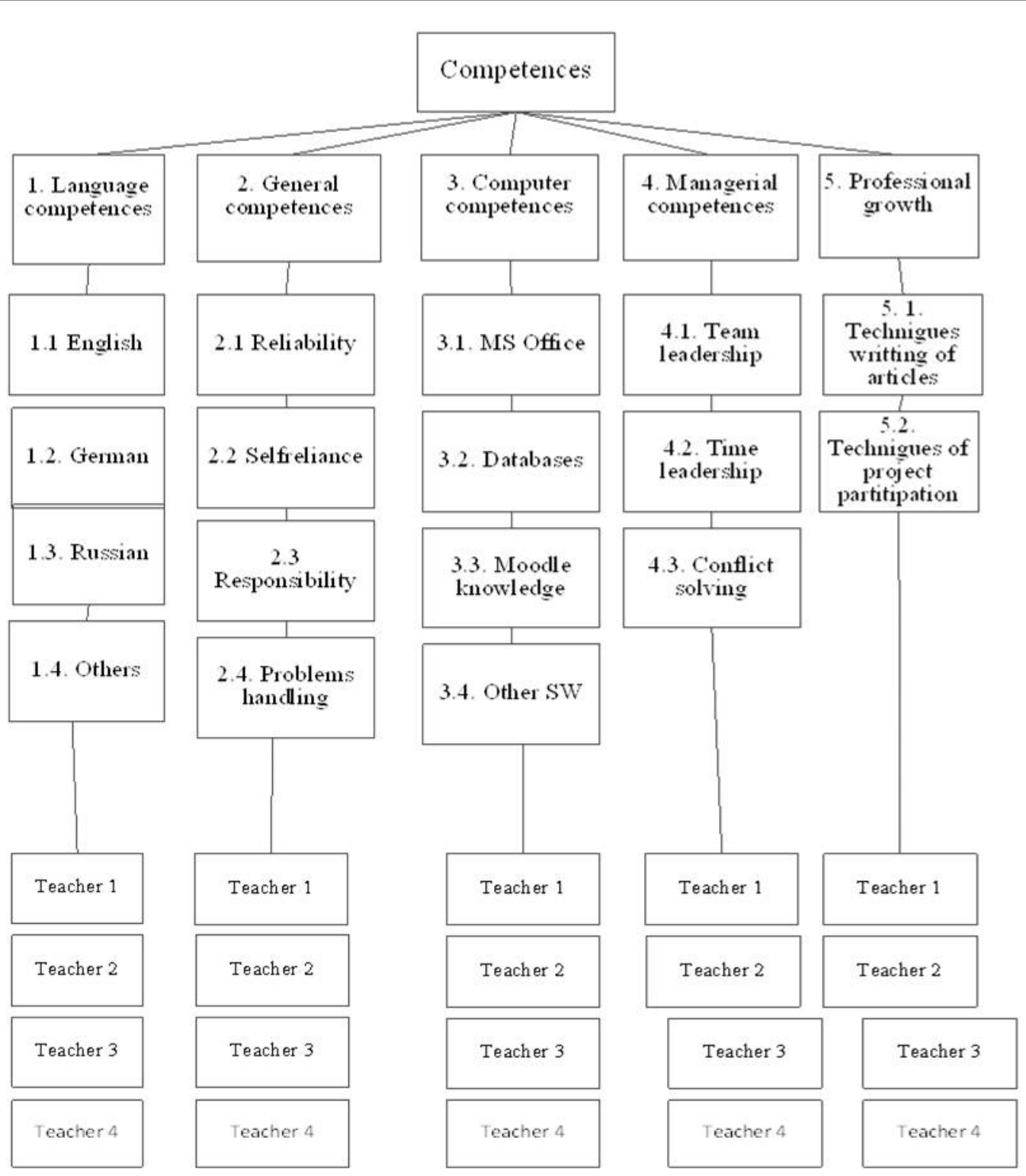

Figure 3. Groups of competences.

By the application of the AHP method, it is necessary to determine partial and global preferences and carry out an evaluation for each teacher at the university.

\section{Results}

Due to the implementation, basic groups commonly used in practice are selected, particularly managerial competency and general competency. Other competency is related to the work carried out- the scientific research and teaching. They are also based on the applicability and the use of IT technologies supporting better perception and understanding of the taught material. For the academic employees, it is also important for their professional development. Therefore, these competencies form another group involved in the competency model. The proposed competency model has composed of five groups competencies-language, general, 
computer, managerial, and professional growth. By using Saaty's matrix, criteria's weights were calculated equal to 1.00. They are the part of AHP method.

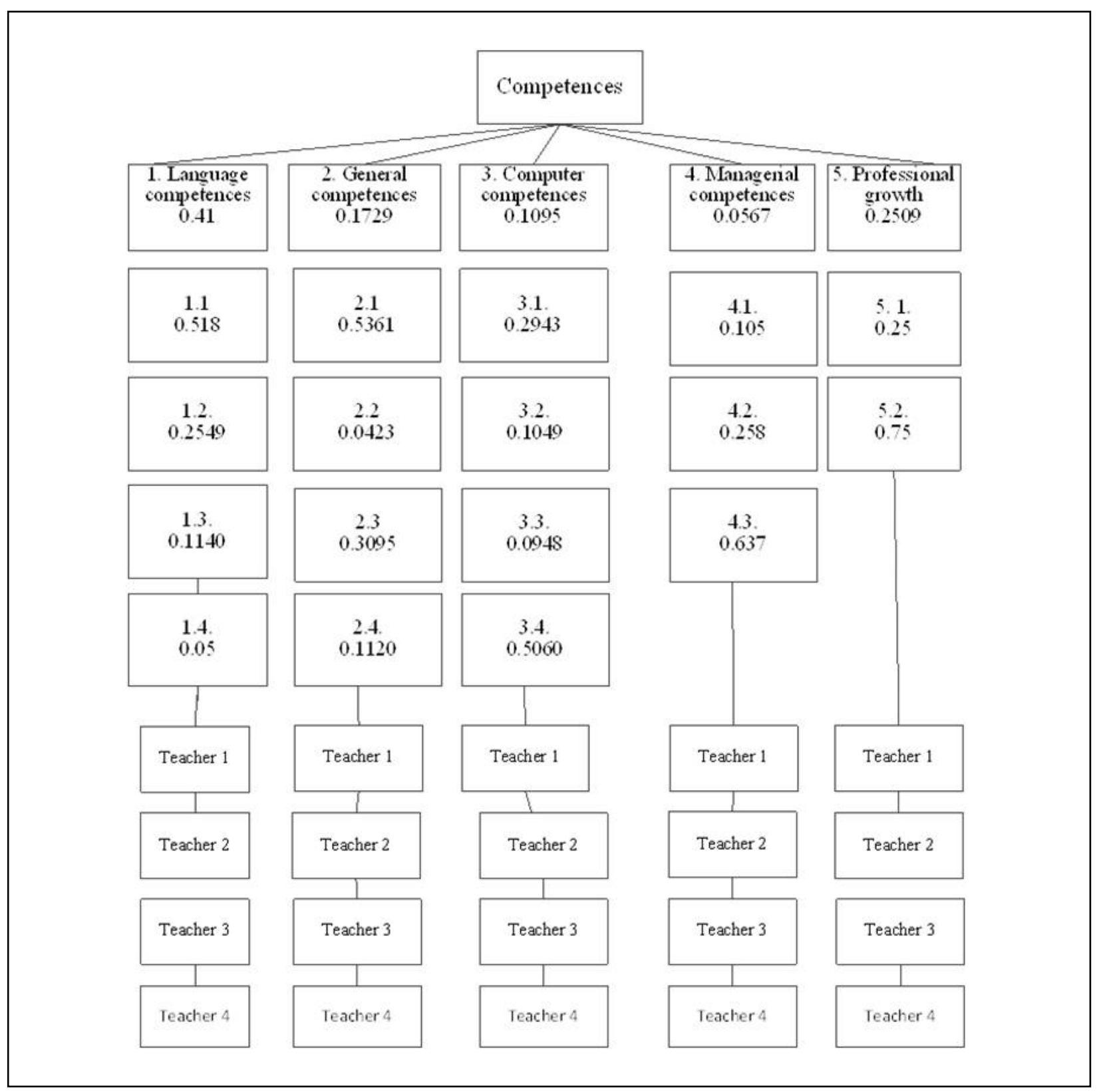

Figure 4. Evaluating of groups of competences by using AHP method.

Groups and individual competencies relevant to the work of the teacher were identified (see Figure 4). Using the AHP method, weights of the preferences between different competencies were determined, as well as global weights of individual competencies (see Table 2).

As we can see, the big significance has been lated at language competences and professional growth competences (see Table 3). Individual local weights of the criteria have been calculated as the product of the global weight of the criterion and the partial weight of the individual sub-criterion (in accordance with the AHP method). Subsequently, the assessment of four teachers at the department has been made and the achieved 
results have been evaluated (see Table 3). The evaluation of four employees at the department using five criteria was performed by the department head.

Table 2

Criteria Evaluation-Local and Global Weights (Own Calculation)

\begin{tabular}{lll}
\hline & Local weight & Global weight \\
\hline 0 & $100 \%$ & AHP \\
1 & $41 \%$ & $41 \%$ \\
1.1 & $58.11 \%$ & $23.83 \%$ \\
1.2 & $25.49 \%$ & $10.45 \%$ \\
1.3 & $11.40 \%$ & $4.67 \%$ \\
1.4 & $5.00 \%$ & $2.05 \%$ \\
2. & $17.29 \%$ & $17.29 \%$ \\
2.1 & $53.61 \%$ & $9.27 \%$ \\
2.2 & $4.23 \%$ & $0.73 \%$ \\
2.3 & $30.95 \%$ & $5.35 \%$ \\
2.4 & $11.20 \%$ & $1.94 \%$ \\
3 & $10.95 \%$ & $10.95 \%$ \\
3.1 & $29.43 \%$ & $3.22 \%$ \\
3.2 & $10.49 \%$ & $1.15 \%$ \\
3.3 & $9.48 \%$ & $1.04 \%$ \\
3.4 & $50.60 \%$ & $5.54 \%$ \\
4 & $5.67 \%$ & $5.67 \%$ \\
4.1 & $10.47 \%$ & $0.59 \%$ \\
4.2 & $25.83 \%$ & $1.46 \%$ \\
4.3 & $63.70 \%$ & $3.61 \%$ \\
5 & $25.09 \%$ & $25.09 \%$ \\
5.1 & $25.00 \%$ & $6.27 \%$ \\
5.2 & $75.00 \%$ & $18.82 \%$ \\
\hline
\end{tabular}

Table 3

Total Assessment (Own Calculation)

\begin{tabular}{lllll}
\hline Groups of criteria & Teacher 1 & Teacher 2 & Teacher 3 & Teacher 4 \\
\hline 1 & 12.3010 & 36.9031 & 24.6021 & 24.6021 \\
2 & 8.6453 & 6.9162 & 10.3743 & 8.6453 \\
3 & 8.7630 & 5.4769 & 7.6676 & 7.6676 \\
4 & 4.5329 & 2.2665 & 5.0996 & 2.8331 \\
5 & 10.0344 & 12.5430 & 22.5774 & 17.5602 \\
Total & 44.2767 & 64.1057 & 70.3210 & 61.3083 \\
Percentage & 52.89 & 76.56 & 84.00 & 73.23 \\
& 4 & 2 & 1 & 3 \\
\hline
\end{tabular}

The department full-time teachers have been assessed. No doctoral students and part-time teachers have been evaluated. Calculation in Table 3 shows that the assessment is converted to a dimensionless value and the total usability is calculated using the weight of the individual criteria. The assessment was calculated as the product of the global weight of the criterion and the usability. The maximum usability is calculated. Values of the calculated total usability are compared and used to determine the order according to the highest usability of the individual employees. The results show that the highest usability was determined for the employee No. 3 
(84\%). Based on the obtained results, it is possible to determine the order of the employees by evaluated competencies. Evaluation based on the use of this method can serve as a basis for remuneration of the academic employees in the organization. Standardly, the assessment should be carried out once per year. Along with the assessment of the performance achieved (in the field of science and in the field of pedagogy), the assessment by competencies should also be taken into account. Mutual assessment of the employees would seem to be optimal, which raises the possibility of applying comparative analysis, but such an assessment is not used in practice nor it can be used.

\section{Conclusion}

The results of evaluation of the different groups showed, that when using the AHP method, the highest weight had the language competencies and professional growth. General competences are at the third position. Furthermore, the research revealed that the best performance, when measured by competencies, has been shown by the teacher No. 3. Based on the performed assessment, the remuneration phase should subsequently occur. AHP methodology is a useful tool for evaluation of competencies as criteria. AHP methodology was implemented in the human resources branch. Competency model of the academic employee and its assessment demonstrated the possibility to use the AHP method as a potential tool for evaluation of the university staff.

\section{References}

Armstrong, M. (2009). Odměňování pracovníků. Praha: Grada Publishing.

Bazsova, B. (2015). Use of Saaty's matrix by performance employee measuring at the university department (pp. 25-35). In R.

Němec and F. Zapletal (Eds.), Proceedings of the 11th International Conference on Strategic Management and its Support by Information Systems 2015 SMSIS 2015, VŠB-Technical University of Ostrava, Uherské Hradiště.

Hronik, F. (2007). Rozvoj a vzděláváni pracovniků. Praha: Grada Publishing.

Koubek, J. (2007). Personální práce v malých a středních firmách. Praha: Grada Publishing.

Majovska, R. (2014). Open source programmes as the support in mathematical education (pp. 341-347). In I. Krejčí, M. Flégl, and

M. Houška (Eds.), Proceedings of the 12th International Conference on Efficiency and Responsibility in Education ERIE 2014, Czech University of Life Sciences Prague, Prague.

Ramik, J., \& Perzina, R. (2008). Moderní metody hodnocení a rozhodování. Slezská univerzita v Opavě, Karviná.

Rehacek, P. (2015). Matrix organization for project management (pp. 160-165). In Proceedings of the 11th International Conference on Strategic Management and its Support by Information Systems (SMSIS), 20-22 May, Uherské Hradiště, Czech Republic.

Saaty, T. L. (1980). The analytic hierarchy process: Planning, priority setting, resource allocation. London: Mc Graw-Hill International Book Co.

Wagnerova, I. (2008). Hodnoceni a řizení výkonnosti. New Jersey: Pearson Publishing. 